\title{
FOREST MANAGEMENT FORUM: OPENING REMARKS
}

\section{By ALAN MOSS*}

I am honoured to have been asked to chair and moderate the Forest Management Forum this afternoon. Our President, Des Crosley, was Chairman of the Forest Management Committee last year and would normally be doing this task. He is, of course, fully occupied with his new duties and, when he asked me to chair this forum, I accepted at once.

Your panel today was unaware when appointed of a situation which came to light a short time ago when the Honourable Mitchell Sharp, Federal Finance Minister, announced that the Federal government intends to terminate the Federal-Provincial Forestry Agreements (authorized under the Canada Forestry Act) when they expire on 31st of March, 1967. This intention was announced as a part of a series of anti-inflationary measures intended to stabilize our economic position. The monies concerned, approximately eight or nine million dollars in all for Canada, were federal contributions to Provincial forestry for the purposes of reforestation, access road construction, forest inventory and forest protection, all vital to forest management in Canada.

Your President has stated his chagrin at this development and Dr. Thiesmeyer, in his luncheon address to us, referred to the urgent need for intensive forest management across Canada. The National Forestry Conference, held in Quebec during February of this year emphasized the need for much more effective forest management now in order to insure that the Canadian forests will be in a condition to meet the anticipated demands upon them in the future-particularly for wood, but also for recreation and other uses.

It is true that no formal resolutions were adopted at the National Conference but, in the summation of Conference results, the main statement pertaining to forest management said that Canada should give:

"greatly increased emphasis to programmes of forest access; protection against fire, insects and disease; reforestation and silviculture."

It is extraordinary that the only federal funds which afford a direct contribution to these activities should be withdrawn entirely in the face of the need so strongly emphasized by virtually all agencies engaged in forestry in Canada, including the Federal government which convened the National Conference.

The overriding need for anti-inflationary measures, in order to stabilize the Canadian economy in its surging growth, will be evident to many. But this does not convince many people that the governmental reduction of expenditure of eight or nine million dollars toward a renewable resource which is supporting an industry, from which the Federal government is receiving a very large current annual revenue in various taxation forms, is justified. Indeed, one may believe that there is an excellent case for a considerable increase in federal re-investment, subject to the availability of professionally and technically

* Consulting Forester, Kelowna, British Columbia. 
trained personnel and labour to apply the funds made available in an effective manner.

Thus, your panel appears before you at a rather critical time for forest management. I will say no more at this point on the subject of finance of management activities.

The Management Committee, in the past year, has worked by correspondence. In order to stimulate thinking and its close relation, controversy, amongst Committee members, our Chairman wrote a series of provocative bulletins under the title of "The Devil's Advocate", now at Issue No. 6 of Volume 3. Members replied with varying degrees of opinion, from agreement to outrage. Our Chairman would summarize the replies in the next issue of "The Devil's Advocate" and so we proceeded. It would be cumbersome to review all of the subjects covered at this time, but they did include such matters as a review of current Crown regulations, as they pertained to advances in forest management in each Province, and the influence of form of tenure on forest management practices.

In Canada, the forest resource by and large, is within the jurisdictions of the several Provincial governments and the difficulties of arriving at a compatible Canadian policy for the management of forests will be obvious to you. Dr. Rousseau has already referred to this problem at a policy level and it has a direct bearing on the Federal contributions to forestry mentioned previously. The same difficulties apply to the work of the Forest Management Committee of this Institute-we are a national committee discussing Provincial jurisdictions. Consequently, our agreed conclusions are ineffective unless virtually unanimous and can seldom be agreements in detail.

We have found, on the average across Canada, that the items of primary concern for management are:

a) More access roads and trails.

b) Better forest protection against all forms of damage.

c) Much improved silvicultural practise, with particular emphasis on reforestation.

d) More management research, but only if better oriented to current management problems.

e) Closer utilization of standing timber.

f) Land and timber inventory programmes.

We have not found unanimous agreement on the specific order of priority of these items and this is perhaps only logical with our forest resources under provincial jurisdictions. A fixed order of priority for Canada would hardly have an equitable, practical application and the lack of such fixed priorities has the distinct merit of retaining flexibility of action.

The panel today speaks on a variety of subjects of national or regional significance and each member expresses his own views. There has been no attempt to co-ordinate these views in a formal way but rather, we may hope to hear a cross-section or spectrum of Canadian management views and problems. 